\title{
EFFECT OF SMELLING AMNIOTIC FLUID ON COMFORT AND CRYING IN PRETERM INFANTS DURING PERIPHERAL CANNULATION: A RANDOMIZED CONTROLLED TRIAL
}

\author{
Dilek Küçük Alemdar ${ }^{1}$ and Fatma Güdücü Tüfekci²
}

\author{
${ }^{1}$ Giresun University, Faculty of Health Sciences, Department of Midwifery, Giresun, Turkey; \\ ${ }^{2}$ Ataturk University, Health Science Faculty, Department of Pediatric Nursing, Erzurum, Turkey
}

\begin{abstract}
SUMMARY - The aim of the study was to investigate the effect of smelling amniotic fluid on comfort and duration of crying caused by peripheral cannulation in preterm infants. This was a randomized controlled trial. The study sample consisted of 80 preterm infants meeting the case selection criteria. The infants were randomly assigned to experimental and control group. Upon exclusion of some infants from the study, total number of infants in both groups was 61 . The infants in the amniotic fluid group smelled amniotic fluid for 15 minutes before, during, and for 15 minutes after the application of peripheral cannulation, whereas the infants in the control group did not undergo any intervention other than routine care. The level of comfort was significantly higher and the duration of crying lower in the infants from the amniotic fluid group as compared with control group before, during and after the procedure. The intervention of smelling amniotic fluid was found to be an effective practice that could be used for reducing the length of crying and increase comfort in preterm infants undergoing peripheral cannulation.
\end{abstract}

Key words: Amniotic fuid; Crying; Catheterization; Infant, newborn; Infant, premature

\section{Introduction}

The previous general belief was that premature infants could not feel and sense pain; nowadays, there is evidence that premature infants can feel pain during surgical procedures. Recent studies show that infants can feel pain after $26^{\text {th }}$ week of gestational age ${ }^{1-4}$. Premature infants are frequently exposed to painful procedures during the first days of their life in neonatal intensive care units (NICU); hence, proposing methods that would calm newborn infants is necessary ${ }^{5,6}$.

Olfactory (smell) system is a special system maturing quite early in the development of sense, with strong

Correspondence to: Assist. Prof. Dilek Küçük Alemdar, MD, Giresun University, Faculty of Health Sciences, Department of Midwifery, 28340 Piraziz-Giresun, Turkey

E-mail: dilek.alemdar@giresun.edu.tr

Received December 14, 2016, accepted October 11, 2017 nutrition ties, and the mother-infant attachment $t^{3,7,8}$. The sense of smell is responsible for the formation of many motor and emotional responses in the brain'. It is known that bad odors reduce and fragrances increase positive responses in babies ${ }^{10}$.

There are various studies including stimulation of olfactory system in term and preterm infants. The smells constituting positive responses include smell of breast milk of the infant's own mother ${ }^{11-13}$, smell of breast milk of other mothers, smell of belongings of mother, smell of amniotic fluid among maternal smells, as well as smell of infant formula and vanilla $a^{10,12-14}$. In this study, results such as gaining weight faster due to becoming calm and spending less energy, feeling less pain, decrease in apnea frequency and severity, starting oral feeding earlier, and decreasing length of hospital stay were obtained ${ }^{13-16}$.

Babies are exposed to many negative stimuli such as strong perfumes or scented cologne, alcohol, clean- 
ing chemicals, alcohol-based hand rubs, and oral medications in NICU. This odor should be reduced or counterweight fragrant established with positive stimuli such as breastfeeding or parent-smelling substanc$\mathrm{es}^{9,11,17}$. Thus, negative physiologic reactions in infants are decreased, a sense of security is developed, and development of the bond between babies and parents is easier if the baby is less likely to experience negative odor. For example, if the baby is exposed to constant smell of alcohol during the blood collection process, he/she will expect a painful process whenever faced with the smell of alcohol and will begin to cry ${ }^{11,18}$.

There are no studies evaluating the effect of smelling amniotic fluid, which may be considered useful in reducing pain and increasing comfort during peripheral cannulation in premature infants. Applications carried out in accordance with the results obtained by this initiative could be supportive in the care of premature infants. The purpose of the study was to investigate the effect of smelling amniotic fluid on the comfort and duration of crying caused by peripheral cannulation in preterm infants.

\section{Research hypotheses}

H1: Making premature infants smell amniotic fluid reduces duration of crying induced by peripheral cannulation.

$\mathrm{H} 2$ : Making premature infants smell amniotic fluid improves comfort during peripheral cannulation.

\section{Materials and Methods}

This was a randomized controlled trial. The study population consisted of preterm infants that received treatment and care in a hospital NICU between June 2014 and October 2015. Power analysis was performed to determine the sample size needed to achieve a 0.90 power in the test at a significance level of 0.05 with a medium level of effect. The study sample consisted of 80 preterm infants meeting the case selection criteria and infants were randomly assigned to either group. However, upon excluding some infants from the study, the total number of infants in the two groups was 61 . The calculated sample size was found to be 61 premature infants randomly assigned to the amniotic fluid $(n=30)$ and control $(n=31)$ groups. The order within the groups was determined by randomization. Ran- domization was performed using a computer program. Selection criteria for inclusion in the study were gestational age of 28-36 weeks; birth weight $\geq 1000$ grams; stable health status at 24 hours of birth; no congenital anomalies; cesarean section with epidural and spinal anesthesia; sepsis or non-sepsis; no enteral nutrition; no blood and meconium stained amniotic fluid during cesarean section (it may change the amniotic fluid smell); and no use of pharmacological or any nonpharmacological pain relief.

\section{Measurement instruments}

The following forms were used to collect data: Premature Infant Information Form developed by the researcher to record natal and postnatal information on the preterm infant, and Premature Infant Comfort Scale (PICS) to assess the level of comfort.

\section{Premature Infant Information Form}

This form includes newborn's age, gender, gestational age, birth weight, birth length, head circumference, Apgar score, nutritional status (breastfeeding and/or formula feeding), and diagnoses.

\section{Premature Infant Comfort Scale}

This scale was developed by Caljouw et al. in $2007^{19}$ for measuring pain and stress levels in preterm infants of $\geq 28$ and $\leq 37$ weeks of gestational age, which was adapted for use in Turkey. Turkish reliability and validity study of PICS was performed by Alemdar and Tüfekçi in $2015^{20}$. PICS is a multidimensional scale used to assess behavioral and psychological comfort and pain. PICS assesses seven elements: alertness, calmness/agitation, respiratory status (only for mechanical ventilation support) or crying (we did not use this parameter in our study because it was meant for children with spontaneous breathing), physical movements, muscle tone, facial movements, and mean heart rate. Each item is scored on a 5-point Likert-type scale from 1 (good) to 5 (poor). The final total score is determined with the aforementioned parameters to yield the infant PICS score, the highest score being 35 and lowest score 7 . A total score of $\geq 17$ points indicates that an intervention is required to relieve discomfort ${ }^{19}$. In their study, Alemdar and Tüfekçi found the Cronbach's alpha value of $0.83^{20}$. 


\section{Duration of crying}

The duration of cannulation (in seconds) from the beginning of cannula insertion to the placement of the plaster was measured by the researcher. The crying time (in seconds) was also noted. For this purpose, crying beginning from the onset of cannula insertion until all crying activity ceased, up to a maximum of three minutes, was recorded by video camera and later analyzed by the same researcher. Total length of crying was defined as the total time during which the subject produced audible distress vocalizations over a 3-minute observation period ${ }^{21}$.

\section{Data collection}

All premature babies admitted to the NICU were taken to the examination room, where they were treated under a radiant warmer. The radiant warmer was kept at a constant temperature (ambient temperature of $37-39^{\circ} \mathrm{C}$ ), and a decibel meter was mounted on the warmer. The room light level was set at about 600 lux. All venipuncture procedures were performed by the same nurse working on the day shift (who had 5-year NICU experience). No pharmacological or non-pharmacological pain relieving methods were applied in infants during peripheral cannulation in NICU where the study was conducted. All factors that could affect the level of pain in preterm infants in both amniotic fluid and control groups were standardized. These factors were as follows: the procedure was administered while the preterm infant was not crying; and if he/she was crying, the staff waited for two minutes. Cephalic and basilic veins were used in all premature infants during the procedure. Before the procedure, the area was cleaned from the center to the periphery with 70\% alcohol as a skin antiseptic in all premature infants. The procedure was performed after waiting for at least 30 seconds. Purple catheter $26 \mathrm{G}$ and yellow catheter $24 \mathrm{G}$ were used in the procedure. A cannula needle was inserted in the tissue at a 15-20 degree angle. Thus, veins were accessed by penetrating the skin and the vein simultaneously. After being sure that the needle was in the vein, catheters were fixed on the skin by using transparent plaster. The interventions applied to the preterm infants in the control and amniotic fluid groups of the study are described below.

The preterm infants in the amniotic fluid group were allowed to smell their own mothers' amniotic fluid; 8-10 cc of amniotic fluid was taken by the physician into a $20-\mathrm{mL}$ injector during cesarean section and kept at $8{ }^{\circ} \mathrm{C}$ in a refrigerator until cannulation. In premature infants hospitalized at NICU, amniotic fluid was fixed $5 \mathrm{~cm}$ away from the infants' noses by pouring it on a big piece of sterilized gauze sponge 15 minutes before peripheral cannulation. The infants were allowed to smell amniotic fluid during the procedure and for up to 15 minutes after the procedure. Images of the baby before, during and after the procedure were recorded on a video recorder.

\section{Ethical considerations}

To conduct this study, we obtained legal permission from the related institution with ethical consent from the Ethics Committee of the Atatürk University. We explained the purpose of this study to the families of the premature infants included in the study and answered their questions. A written informed consent was obtained from the parents of the infants. Parents were assured that the information they provided would be confidential and would not be used anywhere else. In this study, we fulfilled the related ethical principles of the informed consent, voluntariness, and privacy protection of human subjects, and upheld the protection of their individual rights.

\section{Statistical analysis}

The researcher viewed the video recordings after the procedures to evaluate the infants' comfort. Video recordings for both groups were viewed by two NICU nurses and the researcher after the procedure to evaluate comfort, and the researcher's observations were used for data analysis because there was no statistically significant difference according to the result of the inter-observer agreement test performed for comfort (Kendall $=0.651, \mathrm{p}>0.05$ ).

Data were analyzed using the Statistical Package for Social Sciences (SPSS) 18.0 statistical software package. Percentage distribution, mean value, standard deviation, $\chi^{2}$ value, Kendall $\mathrm{W}$ and $t$-test comparison between the groups were used on statistical data analysis.

\section{Results}

No statistically significant difference was found between the control and amniotic fluid groups in terms 
Table 1. Comparison of descriptive characteristics of control and amniotic fluid groups $(N=61)$

\begin{tabular}{|c|c|c|c|c|c|c|}
\hline \multirow{3}{*}{ Characteristic } & \multicolumn{4}{|c|}{ Group } & \multirow[b]{3}{*}{$\chi^{2}$} & \multirow[b]{3}{*}{$p$} \\
\hline & \multicolumn{2}{|c|}{ Control $(\mathrm{n}=31)$} & \multicolumn{2}{|c|}{ Amniotic fluid $(\mathrm{n}=30)$} & & \\
\hline & $\mathrm{n}$ & $\%$ & $\mathrm{n}$ & $\%$ & & \\
\hline $\begin{array}{c}\text { Gender } \\
\text { Girl } \\
\text { Boy } \\
\end{array}$ & $\begin{array}{l}13 \\
18\end{array}$ & $\begin{array}{l}41.9 \\
58.1\end{array}$ & $\begin{array}{l}10 \\
20\end{array}$ & $\begin{array}{l}33.3 \\
66.7\end{array}$ & 0.16 & .32 \\
\hline $\begin{array}{l}\text { Diagnosis } \\
\text { RDS } \\
\text { RDS + IUGR } \\
\end{array}$ & $\begin{array}{l}27 \\
4\end{array}$ & $\begin{array}{l}87.1 \\
12.9\end{array}$ & $\begin{array}{l}28 \\
2\end{array}$ & $\begin{array}{l}93.3 \\
6.7\end{array}$ & 1.10 & 0.19 \\
\hline & $\mathrm{M}$ & & M & & $\mathrm{t}$ & $\mathrm{p}$ \\
\hline $\begin{array}{l}\text { Gestational age }(\mathrm{wks}) \\
\text { Birth weight }(\mathrm{g}) \\
\text { Head circumference }(\mathrm{cm}) \\
\text { Birth length }(\mathrm{cm}) \\
\text { Apgar acore } 1 \mathrm{~min} \\
\text { Apgar score } 5 \mathrm{~min} \\
\end{array}$ & $\begin{array}{l}33.9 \\
229 \\
32.2 \\
45.6 \\
5.80 \\
7.54\end{array}$ & & $\begin{array}{l}31 . \\
173 \\
29 . \\
41 . \\
4.6 \\
6.8\end{array}$ & & $\begin{array}{l}0.73 \\
1.24 \\
0.89 \\
1.45 \\
1.87 \\
1.65\end{array}$ & $\begin{array}{l}0.43 \\
0.87 \\
0.92 \\
0.78 \\
0.54 \\
0.36\end{array}$ \\
\hline
\end{tabular}

$\mathrm{RDS}=$ respiratory distress syndrome; IUGR = intrauterine growth retardation

Table 2. Comparison of the mean Premature Infant Comfort Scale (PICS) scores between amniotic fluid and control groups

\begin{tabular}{|l|l|l|l|l|}
\hline \multirow{2}{*}{ PICS } & \multicolumn{2}{|c|}{ Group } & \multicolumn{2}{|c|}{} \\
\cline { 2 - 5 } & $\begin{array}{l}\text { Control } \\
(\mathrm{n}=31)\end{array}$ & $\begin{array}{l}\text { Amniotic fluid } \\
(\mathrm{n}=30)\end{array}$ & \multicolumn{2}{|c|}{} \\
\cline { 2 - 5 } & Mean \pm SD & Mean \pm SD & t & $\mathrm{p}$ \\
\hline Before peripheral cannulation & $11.76 \pm 3.51$ & $11.03 \pm 4.83$ & -3.45 & 0.05 \\
During peripheral cannulation & $23.41 \pm 5.95$ & $22.45 \pm 5.72$ & -2.31 & 0.05 \\
After peripheral cannulation & $19.63 \pm 7.33$ & $18.11 \pm 6.54$ & -2.40 & 0.05 \\
F and p & $28.49 \quad 0.05$ & 19.620 .05 & & \\
\hline
\end{tabular}

Table 3. Comparison of the mean duration of crying between amniotic fluid and control groups $(N=61)$

\begin{tabular}{|l|l|l|l|l|}
\hline \multirow{2}{*}{ Crying $(\mathrm{s})$} & \multicolumn{3}{|c|}{ Group } & \multicolumn{2}{|c|}{} \\
\cline { 2 - 5 } & $\begin{array}{l}\text { Control } \\
(\mathrm{n}=31)\end{array}$ & $\begin{array}{l}\text { Amniotic fluid } \\
(\mathrm{n}=30)\end{array}$ & \multicolumn{2}{|c|}{} \\
\cline { 2 - 5 } & Mean \pm SD & Mean \pm SD & $\mathrm{t}$ & $\mathrm{p}$ \\
\hline During peripheral cannulation & $102.35 \pm 42.48$ & $91.16 \pm 48.36$ & 8.23 & 0.05 \\
After peripheral cannulation & $68.65 \pm 35.81$ & $55.26 \pm 41.18$ & 6.56 & 0.05 \\
$\mathrm{t}$ and $\mathrm{p}$ & $14.38 \quad 0.05$ & $7.47 \quad 0.05$ & & \\
\hline
\end{tabular}

of gender, gestational age, birth weight, birth length, head circumference, diet, Apgar score at 1 and $5 \mathrm{~min}$, and diagnosis ( $p>0.05)$ (Table 1).

Significant differences were recorded among the levels of comfort before, during and after the proce- dure in both control group and amniotic fluid group infants ( $p<0.05$ both). However, the levels of comfort in infants from the amniotic fluid group were significantly better as compared with control group infants $(\mathrm{p}<0.05)$ (Table 2). 


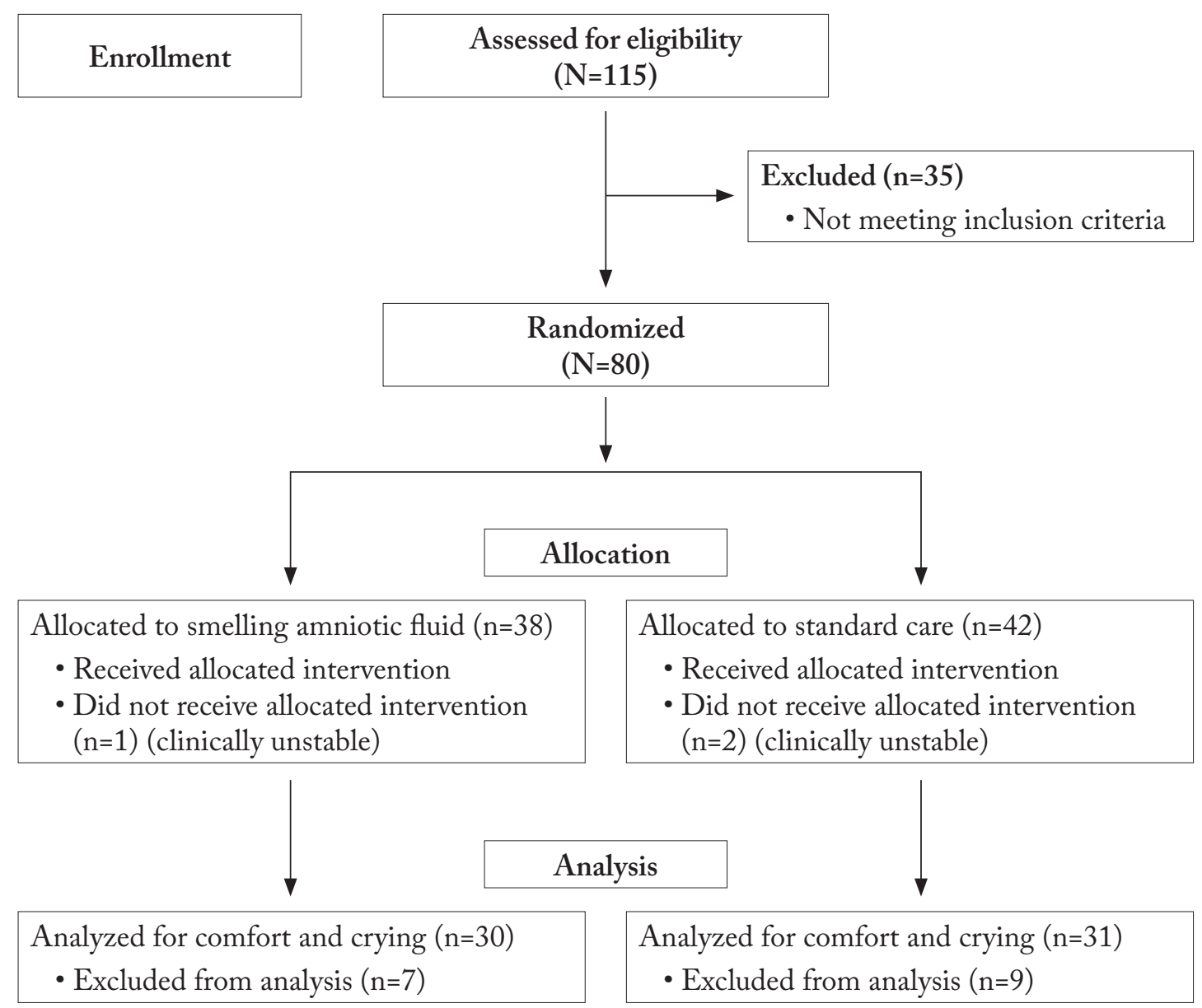

Fig. 1. Flow diagram of preterm infant enrollment in the study of the effect of smelling amniotic fluid on comfort and crying.

Significant differences were found between the lengths of crying during and after the procedure in both control group and amniotic fluid group infants $(\mathrm{p}<0.05$ both). The duration of crying was significantly shorter in infants from the amniotic fluid group as compared with control group infants $(\mathrm{p}<0.05)$ (Table 3$)$.

\section{Discussion}

In this study, the aim was to investigate the effect of smelling amniotic fluid on comfort and duration of crying caused by peripheral cannulation in preterm infants. Significant differences were found among the levels of comfort before, during and after the procedure in the amniotic fluid group $(\mathrm{p}<0.05)$. Fetus inhales smell of amniotic fluid in the intrauterine period and this smell constitutes a chemical stimulus for him/ her. It is observed that this smell helps the baby calm down and adapt to the new environment in the neonatal period ${ }^{15}$. In the literature, it is stated that smells related to mothers represent trust and decrease pain and stress in newborns ${ }^{12-16,22}$.

In the studies conducted in heel lance, it was determined that newborns smelling breast milk of their own mothers felt significantly less pain and had less uneasiness/agitation symptoms ${ }^{14,15}$. In their study, Akcan and Polat ${ }^{23}$ also report that after the heel lance procedure, the pain was less in the newborns from the breast milk and amniotic fluid group compared to the lavender and control groups. The results of these studies support the results of the present study. It could be asserted that smells of mothers with whom newborns feel themselves safe are effective in practices causing pain and stress. 
In the present study, a significant difference was detected in the duration of crying of infants during and after the procedure in the amniotic fluid group $(p<0.05)$. In their study, Varendi et al. ${ }^{15}$ observed that newborns smelling amniotic fluid cried for a shorter time than those in the breast milk smell and control groups. In another study that analyzed the effect of smells on pain, crying infants allowed to smell clothes of their mothers, of another mother, and clothes never used were found to give more positive responses to the smells of their own mothers ${ }^{17}$. In their study, Goubet et $a l .{ }^{8}$ found that the newborns allowed to smell familiar scents during heel lance cried by $32 \%$ less than those in the control group and the group allowed to smell vanilla odor. Rattaz et al. ${ }^{7}$ observed that smells of breast milk and vanilla during heel lance decreased grimaces of newborns and only smell of breast milk was effective in decreasing neonatal stress after heel lance. In their study, Goubet et al. ${ }^{3}$ report that offering vanilla smell to newborns during heel lance and venous blood letting, offering perfume scent for the first time, and offering no scent resulted in less crying and grimaces in the newborns allowed to smell familiar scent. This study and previous studies indicate that allowing newborns smell scents of their mothers is an effective method for relieving the interventional discomfort in newborns.

\section{Study limitations}

The most important limitation of the study was the fact that amniotic fluid could only be obtained in infants born by cesarean section. Another limitation was no double-blinding because comfort evaluation had to be done by watching videos. Since gauze sponge placed near noses of infants during PICS assessment in the amniotic fluid group was seen on videos, it was evident in which group they were involved.

\section{Conclusion}

The individualized developmental care practices to be performed in line with the results obtained by these interventions are believed to provide supportive care of premature infants. In accordance with these results, smelling amniotic fluid in discomfort management of preterm infants, which was one of the study limitations, can be recommended as an effective method to be used in nursing care practices.

\section{Acknowledgment}

The research was financed by the Scientific Research Projects (SRP) of the Management Unit of Giresun University (SAĞ-BAP-A- 250414-42).

\section{References}

1. Giannakoulopoulos X, Sepulveda W, Kourtis P, Glover V, Fisk NM. Fetal plasma cortisol and b-endorphin response to intrauterine needling. Lancet. 1994;344:77-81.

2. Gupta R, Kilby M, Cooper G. Fetal surgery and anaesthetic implications. Continuing education in anaesthesia, Crit Care Pain. 2008;8:71-5. doi: 10.1093/bjaceaccp/mkn004

3. Goubet N, Rattaz C, Pierrat V, Bullinger A, Lequien P. Olfactory experience mediates response to pain in preterm newborns. Dev Psychobiol. 2003;42:171-80. doi: 10.1002/dev.10085

4. Glover V. The fetus may feel pain from 20 weeks. Conscience. 2004;25:7-35.

5. Craig KD, Whitfield MF, Grunau RV, Linton J. Hadjistavropoulos H. Pain in the preterm neonate: behavioral and physiological indices. Pain. 1993;52:287-99.

6. Grunau R, Holsti L, Haley DW, Oberlander T, Weinberg J, Solimano A, et al. Neonatal procedural pain exposure predicts lower cortisol and behavioral reactivity in preterm infants in the NICU. Pain. 2005;113:293-300. doi: 10.1016/j.pain. 2004.10.020

7. Rattaz C, Goubet N, Bullinger A. The calming effect of a familiar odor on full-term newborns. J Dev Behav Pediatr. 2005;26:86-92.

8. Goubet N, Strasbaugh K, Chesney JJ. Familiarity breeds content? Soothing effect of a familiar odor on full-term newborns. J Dev Behav Pediatr. 2007;28:189-94. doi: 10.1097/dbp. 0b013e31802d0b8d

9. Lutes LM, Graves CD, Jorgensen KM. The NICU experience and its relationship to sensory integration. In: Kenner C, McGrath JM, eds. Developmental Care of Newborns and Infants: a Guide for Health Professionals. St. Louis: Elsevier; 2004; p. 157-81.

10. Marlier L, Schaal B, Gaugler C, Messer J. Olfaction in premature human newborns: detection and discrimination abilities two months before gestational term. In: Marchlewska-Koj et al., eds. Chemical Signals in Vertebrates. New York: Kluwer Academic Plenum Publishers, 2001; p. 205-9. doi: 10.1016/j. clp.2004.04.003

11. Yildiz A, Arikan D, Gözüm S, Taştekin A, Budancamanak I. The effect of the odor of breast milk on the time needed for transition from gavage to total oral feeding in preterm infants. J Nurs Scholarship. 2011;43:265-73. doi: 10.1111/j.1547-5069. 2011.01410.x

12. Bingham PM, Churchill D, Ashikaga T. Breast milk odor via olfactometer for tube-fed, premature infants. Behav Res Methods. 2007;39:630-4. doi: 10.3758/BF03193035 
13. Raimbault C, Saliba E, Porter RH. The effect of the odour of mother's milk on breastfeeding behaviour of premature neonates. Acta Paediatr.2007;96:368-71. doi:10.1111/j.1651-2227. 2007.00114.x

14. Nishitani S, Miyamura T, Tagawa M, Sumi M, Takase R, Doi $\mathrm{H}$, Moriuchi $\mathrm{H}$, Shinohara K. The calming effect of a maternal breast milk odor on the human newborn infant. Neurosci Res. 2009;63:66-71. doi: 10.1016/j.neures.2008.10.007.

15. Varendi H, Christensson K, Porter RH, Winberg J. Soothing effect of amniotic fluid smell in newborn infants. Early Hum Dev. 1998;51:47-55.

16. Sullivan RM, Toubas P. Clinical usefulness of maternal odor in newborns: soothing and feeding preparatory responses. Biol Neonate. 1998;74:402-8.

17. Muslu GK. Arranging the physical environment in the neonatal intensive care unit. $3^{\text {rd }}$ National Congress of Pediatric Nursing Book. Izmir: Congress Book, 2011; 9-13.

18. Hennessy AC. Routine care of the healthy newborn. In: De Kock J, Walt C, eds. Maternal and Newborn Care: a Complete
Guide for Midwives and Other Health Professionals. Pretoria: Juta Academic, 2004; p. 3-40.

19. Caljouw MAA, Kloos MAC, Olivier MY, Heemskerk IW, Pison Winke CR, Stigter GD, Verhoef JH. Measurement of pain in premature infants with a gestational age between 28 to 37 weeks: validation of the adapted comfort scale. J Neonatal Nurs. 2007;13:13-8. http://dx.doi.org/10.1016/j.jnn.2006.11.007

20. Alemdar DK, Tüfekçi FG. The reliability and validity of the premature infant comfort scales. J Educ Res Nurs. 2015;12: 142-8. doi:10.5222/HEAD.2015.142

21. Lewindon PJ, Harkness L, Lewindon N. Randomised controlled trial of sucrose by mouth for the relief of infant crying after immunization. Arch Dis Child. 1998;79:465-6.

22. Kane FM, Brodie EE, Coull A, et al. The analgesic effect of odour and music upon dressing change. Br J Nurs. 2004;13: 4-12. doi: 10.12968/bjon.2004.13.Sup4.16343

23. Akcan E, Polat S. Comparative effect of the smells of amniotic fluid, breast milk, and lavender on newborns' pain during heel lance. Breastfeed Med. 2016;11:309-14. doi:10.1089/ bfm.2015.0174

Sažetak

\section{UČINAK MIRISA PLODNE VODE NA SMIRENOST I PLAČ NEDONOŠČADI TIJEKOM UVOĐENJA PERIFERNE KANILE: RANDOMIZIRANO KONTROLIRANO ISTRAŽIVANJE}

\section{K. Alemdar i F. G. Tüfekci}

Cilj ovoga randomiziranog kontroliranog istraživanja bio je ispitati učinak mirisa plodne vode na smirenost i trajanje plača uzrokovanog postavljanjem periferne kanile kod nedonoščadi. Istraživanje je provedeno na uzorku od 80 nedonoščadi koja su odgovarala kriterijima za odabir i nasumce su uključena u ispitnu i kontrolnu skupinu. Nakon isključenja neke dojenčadi iz istraživanja ostalo je ukupno 61 dojenče u objema skupinama. Dojenčad u skupini s plodnom vodom mirisala je plodnu vodu 15 minuta prije, tijekom i 15 minuta nakon postavljanja periferne kanile, dok u dojenčadi iz kontrolne skupine nije bilo nikakve dodatne intervencije osim rutinske skrbi. Utvrđeno je da je razina smirenosti bila značajno viša u skupini dojenčadi s mirisanjem plodne vode, dok je trajanje plača bilo kraće u ovoj skupini u usporedbi s kontrolnom skupinom bez mirisanja plodne vode. Mirisanje plodne vode učinkovita je intervencija koja se može primijeniti kako bi se smanjio plač i povećala smirenost nedonoščadi tijekom uvođenja periferne kanile.

Ključne riječi: Amnionska tekućina; Plakanje; Kateterizacija; Novorodenče; Nedonošč 